https://doi.org/10.31470/2706-7904-2021-16-289-293

\title{
СЕМАНТИКА ОБРАЗУ СТАРОСТІ У СПРИЙМАННІ ОСІБ ДОРОСЛОГО ВІКУ
}

\section{Semantics of the Image of Old Age in the Perception of Adults}

\author{
Natalya Tokareva \\ Dr. Sc. in Psychology, Professor \\ Kryvyi Rih State Pedagogical University (Ukraine) \\ tokareva152681@gmail.com \\ https://orcid.org/0000-0003-1428-3729
}

\begin{abstract}
The paper considers the results of the analysis of the problem of reflecting the subjective image of old age in perceptions of respondents of adulthood. Empirical research of the semantic characteristics of the concept of «old age» was carried out through a directed associative experiment and content analysis indicating the absolute frequency of each associate. It was proved that the semantic of the image of old age in perceptions of different generations differs significantly: in early adulthood, respondents are more focused on physiological markers of aging, middle-aged people are primarily concerned about social insecurity and financial constraints of the elderly; representatives of the gerontological group represent the most congruent image of old age, which integrates biological, sociocultural and psychological markers of aging in its structure.
\end{abstract}

Key words: old age, the image of old age, aging, social perception, adults.

\section{Вступ \\ Introduction}

Однією із тривожних тенденцій розвитку цивілізації XXI століття є глобальне старіння людства, що спричиняє демографічний дисбаланс суспільства та породжує суттєві гуманітарні проблеми. Відповідно, наукові дослідження у проблемному полі форматування соціально прийнятних установок людства щодо сприймання старості як самодостатнього етапу життя людини, і зокрема - дослідження психологічних, психолінгвістичних аспектів уявлень представників різних поколінь про людей похилого віку, набувають актуального і практико-орієнтованого характеру.

Науковцями беззаперечно визнається варіативний характер усвідомлення концептосфери старіння і прийняття старості людьми похилого віку, проте системний аналіз наукового контенту досліджень феноменології старості доводить значимість 
метакогнітивного контексту розуміння семантики старості соціальною спільнотою. Про це свідчать, передусім, дослідження клінічних психологів (Huang et al., 2017: 127-131) та науковців соціально-психологічного спрямування (Tang et al., 2021), які доводять, що на якості життя людей у період старості суттєво позначаються індикативні маркери суб' єктивного сприймання віку; інтерпретуючи засвоєний досвід життєтворення, людина вибудовує особистісні конструкти й надалі послуговується ними, упорядковуючи власне життя у період пізньої зрілості й адекватно форматуючи соціальні уявлення про семантику старості.

Метою даного емпіричного дослідження було обрано аналіз семантики концепту «Старість» в уявленні осіб дорослого віку. Логічна схема дослідження уявлень респондентів про старість грунтувалася на твердженні про можливість аналізу ментальних конструктів свідомості за допомогою мовленнєвих висловлювань, що відображують систему внутрішнього психічного світу людини.

\section{Методи та методики дослідження Methods and Techniques of the Research}

Емпіричне дослідження концептосфери поняття «Старість» здійснювалося шляхом скерованого асоціативного експерименту. Вибіркова сукупність була представлена 152 респондентами різного віку (від 20 до 93 років), що проживають на території України.

Емпіричні дані були отримані шляхом індивідуального опитування (усного та письмового) респондентів (73\% звітів) та за допомогою Google-форми (27\% відповідей). Матеріалом дослідження стали 345 наданих респондентами текстових фрагментів що форматувалися за логіко-смисловою схемою «Старість - це ...» та іiі модифікаціями асоціативного типу.

Інформативні результати дослідження були опрацьовані методом кількісного та якісного контент-аналізу, що дозволив окреслити асоціативне поле досліджуваного концепту із зазначенням абсолютної частотності (absolute frequency) кожного асоціату у площиині онтогенетичного вимірювання.

\section{Результати \\ Results}

Вивчення кількісних показників абсолютної частоти (abs_freq) використання маркерів форматування семантичного поля концептосфери суб'єктивного образу старості в уявленні респондентів засвідчило значимість у досліджуваному континуумі 
асоціативних елементів, що конкретизуються у вимірах фізіологічних параметрів старіння: «старість - це період, коли усі системи організму в'януть, коли тіло вмирає...; старість - тривалий період розумової і фізичної руйнації, що закінчується смертю». Подальше ранжирування частотності використання асоціативних елементів, пов'язаних із уявленнями респондентів щодо фізіологічної сторони старіння, дозволило констатувати:

- на стадії ранньої дорослості респонденти фокусують увагу передусім на функціональних обмеженнях (abs_freq 0.58) та на фізіологічних змінах зовнішності (abs_freq 0.56) людей похилого віку. Старість асоціюється представниками даної вікової групи із втратою можливостей, функцій, сфер діяльності, патернів поведінки, котрі ще доступні людині у період ранньої дорослості;

- учасники дослідження стадії середньої дорослості при обговоренні соціальних уявлень про старість найбільш значимим вважають фактор погіршення здоров'я (поліморбідність, загострення хвороб) осіб геронтологічної групи (abs_freq 0.46);

- на стадії пізньої дорослості респонденти засвідчують значимість у семантиці концепту «Старість» таких маркерів як функціональні обмеження (abs_freq 0.62) та погіршення здоров'я (abs_freq 0.43) людей похилого віку;

- найбільш високі (max abs_freq) показники частоти використання фізіологічних маркерів виявляються в уявленнях щодо старості і старіння респондентів пізнього (abs_freq 0.62) та раннього (abs_freq 0.58) періодів дорослішання. Це може бути пов'язано з тим, що люди похилого віку вже усвідомлюють неминучість власного старіння, тоді як особи раннього періоду дорослості сприймають природу старості на контрасті із власним ресурсом життєтворення.

Достатньо представленими у межах семантичного поля концептосфери старості є соціокультурні маркери: «старість - це пенсія і забуття; старість - це період, коли скорочується коло друзів...». Аналіз базових конструктів образу старості, представлених у асоціативних схемах респондентів, засвідчив:

- $\quad$ на стадії ранньої дорослості для респондентів значимим фактором старіння $\epsilon$ згортання діапазону соціальних ролей, відсторонення людей похилого віку від соціокультурного життя (abs_freq 0.43); 
- особи віку середньої дорослості у своїх соціокультурних уявленнях про старість роблять акцент на фінансових обмеженнях і соціальній незахищеності людей похилого віку (abs_freq 0.71);

- для респондентів, що належать до віку пізньої дорослості, значимими у семантичному вимірі образу старості є такі маркери як змінення векторів соціальних зв'язків (орієнтованість на сім’ю, згортання трудових відносин) (abs_freq 0,68) та фінансові обмеження і соціальна незахищеність (abs_freq 0.62) людей похилого віку;

- найбільш високі (max abs_freq) показники частоти використання соціокультурних маркерів виявляються в уявленнях щодо старості i старіння респондентів середнього (abs_freq 0.71) та пізнього (abs_freq 0.68) періодів дорослішання.

Важливу роль у семантичному полі атрибутивного означення образу старості відіграє також блок психологічних маркерів: «старість - це усвідомлення усіма фібрами душі, як кожний фрагмент вашого Я зраджує вас; старість - це період, коли людина забуває про себе, хоронить свої мрії». Вивчення семантичних маркерів образу старості в уявленнях респондентів різного віку доводить:

- найбільш цінним психологічним маркером старості респонденти на стадії ранньої дорослості вважають значний життєвий досвід людей похилого віку, можливість його творчого переосмислення та використання (можливість актуалізації суб'єктивних ресурсів людини - саморозвиток, хобі, мандрівки) (abs_freq 0.32);

- респонденти віку середньої дорослості у архітектоніці своїх психологічних уявлень про старість поєднують визнання цінності значного життєвого досвіду людей похилого віку та можливості його переосмислення, використання у вимірах самоздійснення (abs_freq 0.37) із суб'єктивними переживаннями руйнації організму, власної непотрібності, самотності (abs_freq 0.34);

- геронтологічна група респондентів у архітектоніці образу старості серед психологічних маркерів робить акцент на суб'єктивних переживаннях руйнації організму, власної непотрібності, самотності, страху смерті (abs_freq 0.76). Означене може бути детерміновано недостатністю економічної і соціальної захищеності людей похилого віку у країні періоду кризового реформування;

- найбільш високі (max abs_freq) показники частоти використання психологічних маркерів (i передусім негативного вектору значимості) 
зафіксовані в уявленнях щодо старості і старіння респондентів пізнього періоду дорослішання (abs_freq 0.76).

\section{Висновки Conclusions}

Осмислення семантики концептосфери поняття «Старість» в уявленні представників різних поколінь періоду дорослості дозволяє констатувати складну інтегративну обумовленість ментального континууму людини й окреслити предиктори розуміння феноменології старості у несталому соціальному середовищі.

Узагальнюючи результати емпіричного дослідження, можна наголосити, що архітектоніка образу старості в уявленнях представників різних поколінь суттєво різниться: у ранньому дорослому віці респонденти більш концентруються на фізіологічних маркерах старіння, представники віку середньої дорослості переймаються передусім соціальною незахищеністю та фінансовими обмеженнями людей похилого віку; більш адаптовані до статусу людини похилого віку представники геронтологічної групи являють найбільш конгруентний образ старості, що інтегрує у своїй структурі біологічні, соціокультурні та психологічні маркери старіння. Результати дослідження крім того засвідчили суперечливу конотацію змістової сутності феноменології старості в уявленні дорослих респондентів: досліджуваний концепт асоціюється із мудрістю, досвідченістю (позитивна конотація) й водночас - із браком життєвих сил та немічністю людини, із соціальним відстороненням (негативно марковані конотації). Тож у вимірах стрімких змін для соціальної спільноти вкрай важливим вважаємо формування позитивно зорієнтованих установок щодо старості, адекватного ставлення громади до проблем старіння, зниження рівня ейджизму та геронтофобії. Означене потребує інтегрального підходу до висвітлення геронтологічних проблем психологічною наукою.

\section{Література \\ References}

Huang, T.T., Li, Y., \& Wang, D.H. (2017). Influence of subjective age on quality of life in older adults: Mediation of depression and anxiety. Chinese Journal of Clinical Psychology, 25(1), 127-131. https://doi.org/10.16128/j.cnki.1005-3611.2017.01.028

Tang, M., Wang, D., \& Guerrien, A. (2021). Effect of «freedom of choice» on Task Performance and Well-Being During Leisure Activity: An Intercultural Study Among Older Adults in China and France. International Journal of Aging and Human Development. https://doi.org/10.1177/00914150211037656 